\title{
Effect of the Identity of Xaa on the Fragmentation Modes of Doubly-Protonated Ala-Ala-Xaa-Ala-Ala-Ala-Arg
}

\author{
Alex G. Harrison
}

Department of Chemistry, University of Toronto, 80 St. George Street, Toronto, ON, M5S 3H6, Canada

\begin{abstract}
The product ion mass spectra resulting from collisional activation of doubly-protonated tryptic-type peptides Ala-Ala-Xaa-Ala-Ala-Ala-Arg have been determined for Xaa = Ala $(A)$, $\operatorname{Ser}(S), \operatorname{Val}(\mathrm{V}), \operatorname{Thr}(\mathrm{T})$, Ile(I), $\operatorname{Phe}(\mathrm{F}), \operatorname{Tyr}(\mathrm{Y})$, Sar, $\operatorname{Met}(\mathrm{M}), \operatorname{Trp}(\mathrm{W})$, Pro(P), and $\mathrm{Gln}(\mathrm{Q})$. The major fragmentation reaction involves cleavage of the second amide bond (counting from the $\mathrm{N}$-terminus) except for Xaa $=$ Ser and Thr where elimination of $\mathrm{H}_{2} \mathrm{O}$ from the $[\mathrm{M}+2 \mathrm{H}]^{+2}$ ion forms the base peak. In general, the extent of cleavage of the second amide bond shows little dependence on the identity of Xaa and little dependence on whether the bond cleavage involves symmetrical bond cleavage to form a $y_{5} / b_{2}$ ion pair or asymmetrically to form $y_{5}{ }^{+2}$ and a neutral $b_{2}$ species. Notable exceptions to this generalization occur for Xaa equal to Pro or Sar. For Xaa = Pro only cleavage of the second amide bond is observed, consistent with a pronounced proline effect, i.e., cleavage $\mathrm{N}$-terminal to Pro. When $\mathrm{Xaa}=\mathrm{Sar}$ considerably enhanced cleavage of the second amide bond also is observed, suggesting that at least part of the proline effect relates to the tertiary nature of the amide nitrogen. In the competition between symmetric and asymmetric bond cleavage an attempt to establish a linear free energy correlation in relating $\ln \left(\mathrm{y}_{5}{ }^{+2} / \mathrm{y}_{5}\right)$ to $\mathrm{PA}(\mathrm{H}-\mathrm{Xaa}-\mathrm{OH})$ did not lead to a reasonable correlation although the trend of increasing $\mathrm{y}_{5}+2 / \mathrm{y}_{5}$ ratio with increasing proton affinity of $\mathrm{H}-\mathrm{Xaa}-\mathrm{OH}$ was clear. Proline showed a unique behavior in giving a much higher $\mathrm{y}_{5}+2 / \mathrm{y}_{5}$ ratio than any of the other residues studied.
\end{abstract}

Key words: Proline effect, Symmetric bond cleavage, Asymmetric bond cleavage, Tryptic-type peptides

\section{Introduction}

$\mathrm{T}$ andem mass spectrometry (MS/MS) has developed into a powerful technique for deriving sequence information for peptides and proteins [1-3], with collision-induced dissociation (CID) of protonated or multiply-protonated species commonly being used. In protein sequencing it is common to submit the protein to tryptic digestion and to study the tryptic peptides produced. Such tryptic peptides

Correspondence to: Alex G. Harrison; e-mail: aharriso@chem.utoronto.ca usually have the highly basic Lys or Arg residue at the Ctermini. These basic residues will localize a proton on the basic site [4] which often leads upon CID to fragmentation associated with the basic site rather than cleavage along the backbone, which gives sequence information. Consequently, fragmentation of doubly- or multiply-protonated peptides, in which there is a mobile proton, often provides more complete sequence information.

Although there have been many detailed studies of the fragmentation of singly-protonated non-tryptic peptides which have revealed much mechanistic information $[5,6]$, 
considerably less is known in detail concerning the fragmentation of doubly-protonated tryptic peptides. There have been several limited mechanistic studies [7-14] and equally important information has come from statistical analyses of data bases of tandem mass spectra of tryptic peptides [15-17]. Of particular relevance in the present context is the recent study by Zubarev and co-workers [17], which showed a bifurcating fragmentation behavior of doubly-protonated tryptic peptides in charge-separation reactions (symmetric bond cleavage $[12,14]$ ) in that there is a class of peptides (Class I) where cleavage of the second amide bond is clearly preferred; this preference is particularly evident for shorter chain length peptides, while larger peptides (Class II) tend not to show such a preference [11, 17]. In the initial study [17], it was proposed that the preferential symmetrical cleavage of the second amide bond was the result of formation of a protonated diketopiperazine structure for the $b_{2}$ ion formed by charge separation rather than the more common protonated oxazolone structure [6]. However, it should be noted that recent studies $[18,19]$ have cast doubt on this interpretation and the reasons for the preferred cleavage of the second amide bond in smaller tryptic peptides remain unclear.

In the present study we have determined the product ion mass spectra for doubly-protonated tryptic-type peptides Ala-Ala-Xaa-Ala-Ala-Ala-Arg. The C-terminal Arg localizes one proton at the C-terminus [4] with the other proton being mobile. The spacer residues (Ala) have been kept constant while Xaa was varied. This provides the opportunity to explore the effect of individual Xaa residues on the propensity for cleavage of the second amide bond. Amide bond cleavage may occur symmetrically to produce a singlycharged $y$ ion and the corresponding $b$ ion or asymmetrically to produce a doubly-charged $\mathrm{y}$ ion and a neutral $\mathrm{b}$ species $[12,14]$. The present study also provides substantial information concerning the effect of the Xaa variable residue on this fragmentation competition. For example, Aebersold and co-workers [20] have reported that the Pro residue promotes asymmetric amide bond cleavage $\mathrm{N}$-terminal to the Pro residue although no information was presented concerning the extent of symmetric cleavage of the same bond.

\section{Experimental}

All experimental work was carried out using an electrospray/ quadrupole/time-of-flight (QqTOF) mass spectrometer (QStarXL; MDS SCIEX, Concord, Canada). MS/MS experiments were carried out in the usual fashion by mass selecting the ions of interest with the mass analyzer Q followed by CID in the quadrupole collision cell $\mathrm{q}$ and mass analysis of the ionic products with the time-of-flight analyzer. In the study of fragment ions (pseudo-MS ${ }^{3}$ experiments) CID in the interface region produced fragment ions with those of interest being selected by the quadrupole mass analyzer $\mathrm{Q}$ for fragmentation and analysis in the usual manner. By varying the collision energy in the collision cell breakdown graphs expressing, in a qualitative way, the energy dependence of the fragmentation reactions were constructed. The cone voltage in the interface region was adjusted to give the best precursor ion signal for the ions of interest; in particular, it was found best to use a low cone voltage for transmission of doubly-charged ions.

The peptide samples, at micromolar concentrations, were introduced into the electrospray source in $1: 1 \mathrm{CH}_{3} \mathrm{OH}: 1 \%$ aqueous formic acid by a syringe pump at a flow rate of $10 \mu \mathrm{L} \min ^{-1}$. Nitrogen was used as nebulizing and drying gas and as collision gas in the quadrupole collision cell. Doubly-charged ion signals were identified by the half-mass separation of the isotopic peaks.

All peptides were obtained from Celtek Peptides (Nashville, $\mathrm{TN})$ and showed no impurities in their mass spectra. Consequently, they were used as received.

\section{Results and Discussion}

The product ion mass spectra at $28 \mathrm{eV}$ collision energy for the doubly-protonated peptides Ala-Ala-Xaa-Ala-Ala-AlaArg are presented in Figures 1, 2 and 3 for Xaa $=$ Ala(A), $\operatorname{Ser}(\mathrm{S}), \operatorname{Val}(\mathrm{V}), \operatorname{Thr}(\mathrm{T}), \operatorname{Ile}(\mathrm{I}), \operatorname{Phe}(\mathrm{F}), \operatorname{Tyr}(\mathrm{Y}), \operatorname{Sar}, \operatorname{Met}(\mathrm{M})$, $\operatorname{Trp}(\mathrm{W})$, Pro(P), and $\mathrm{Gln}(\mathrm{Q})$. The results for Pro have been presented previously [14] and are included here for comparison. With the exception of the peptides containing Ser and Thr, the spectra are dominated by doubly- and singly-charged $\mathrm{y}$ ions and by $\mathrm{b}$ ions. For the peptides containing Ser and Thr the base peak corresponds to elimination of $\mathrm{H}_{2} \mathrm{O}$ from the $[\mathrm{M}+2 \mathrm{H}]^{+2}$ ions. There have been several reports [21-25] of the loss of the side chain hydroxyl as $\mathrm{H}_{2} \mathrm{O}$ in the fragmentation of protonated serine and threonine and derivatives. Recently, Stein and coworkers [26] have reported observation of substantial loss of $\mathrm{H}_{2} \mathrm{O}$ from doubly-protonated tryptic peptides containing a single Ser or Thr in the second or third position (counting from the N-terminus) but a much lower extent of $\mathrm{H}_{2} \mathrm{O}$ loss when these residues were further from the $\mathrm{N}$-terminus. A detailed study of the structure(s) and fragmentation reactions of the $\left[\mathrm{M}+2 \mathrm{H}-\mathrm{H}_{2} \mathrm{O}\right]^{+2}$ will be the subject of a future publication.

In a number of cases, signals are observed for the iminium ion, $\operatorname{Im}_{X}$, of the variable residue $X a a$ as well as the $b_{2}$ and $a_{2}$ ions resulting from further fragmentation of the $\mathrm{y}_{5}{ }^{+2}$ product. Such $\mathrm{b}_{2}$ ions are observed at $m / z$ 171(V), 185(I), 219(F), 235(Y). and 203(M). Figure 4 shows, as an example, the breakdown graph for the $\mathrm{y}_{5}{ }^{+2}$ ion (doubly-protonated IAAAR) derived from AAIAAAR. The two fragmentation modes observed are symmetric cleavage of the first and second amide bonds, the former leading to $\mathrm{y}_{4}$ and $\mathrm{Im}_{\mathrm{I}}$ and the latter leading to $y_{3}$ and the IA $b_{2}$ ion at $m / z 185$, with some further fragmentation of the $b_{2}$ ion at higher collision energies to give the $\mathrm{a}_{2}$ ion at $m / z$ 157. Symmetric cleavage of the first and second amide bonds was observed for all $\mathrm{y}_{5}{ }^{+2}$ ions studied, the relative yields of $y_{3}$ and $y_{4}$ showing some dependence on the identity of the Xaa residue at the N-terminus. 

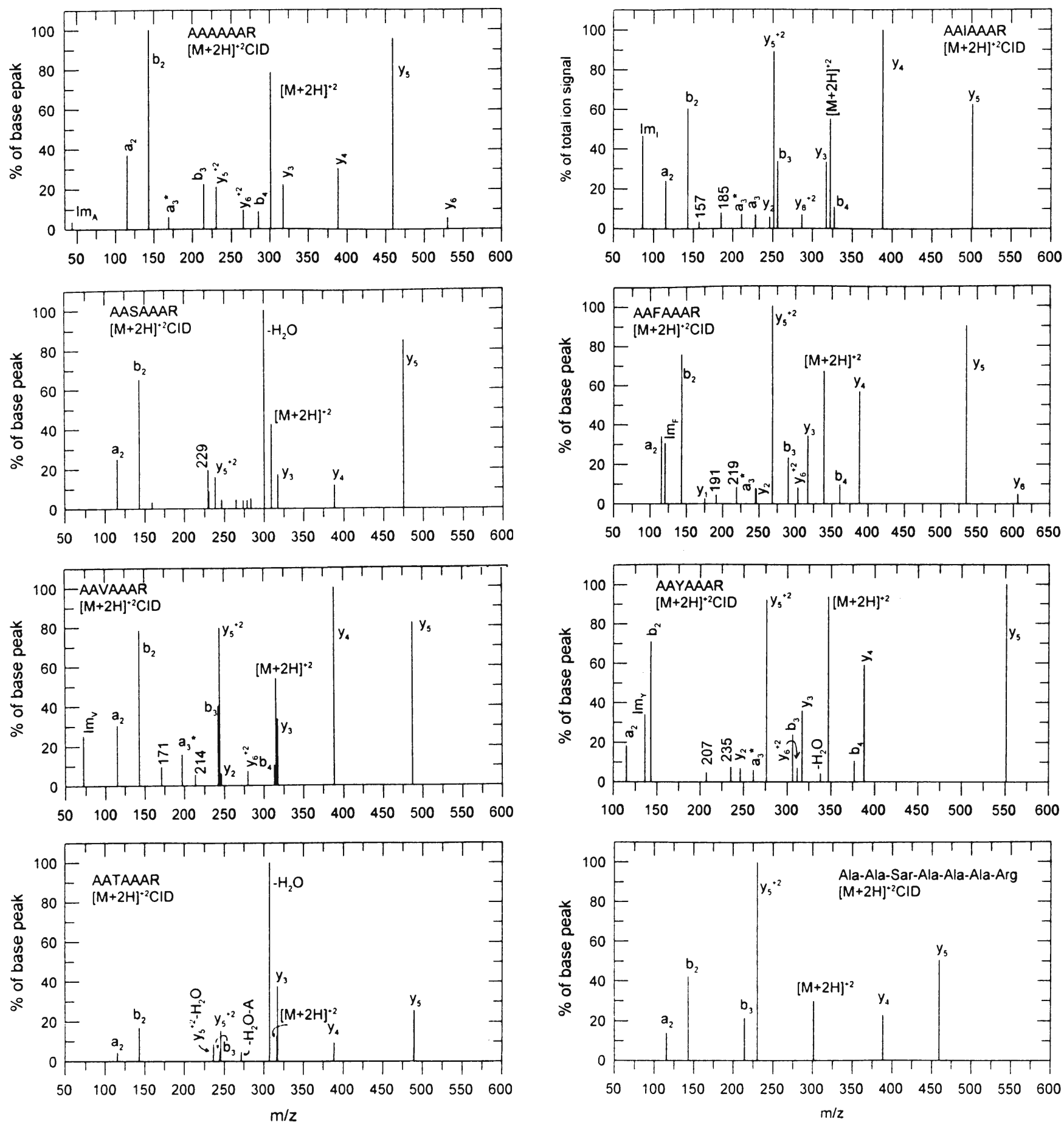

Figure 1. $[\mathrm{M}+2 \mathrm{H}]^{+2}$ product ion mass spectra when $\mathrm{Xaa}=$ Ala, Ser, Val, and Thr

Table 1 lists the $\%$ of total ionization observed for each y ion (including $\mathrm{y}_{5}{ }^{+2}$ ) at $24 \mathrm{eV}$ collision energy (12 V applied potential), where further fragmentation is minimal. Also included in the table are the $\%$ of total ionization for the sum of all y species and the intensity (as \% of total ionization) for the unfragmented $[\mathrm{M}+2 \mathrm{H}]^{+2}$ ions. Table 2 translates these data into the fractional cleavage of each amide bond (counting from the N-terminus); for amide bond 2 the

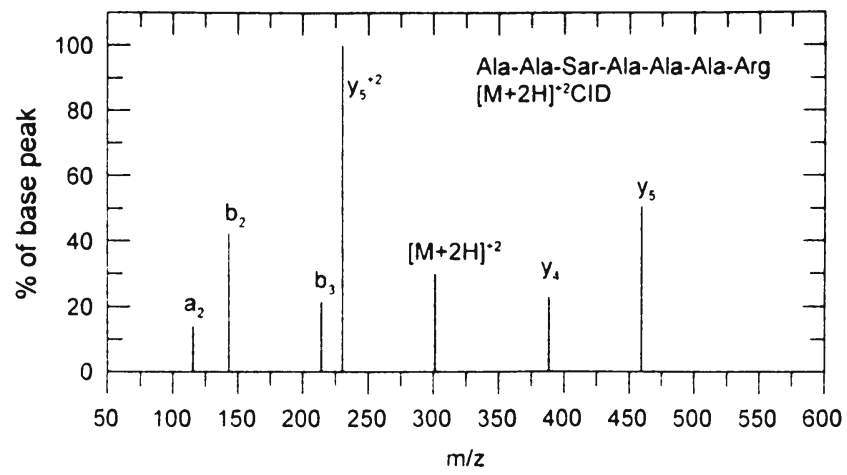

Figure 2. $[\mathrm{M}+2 \mathrm{H}]^{+2}$ product ion mass spectra when $\mathrm{Xaa}=$ Ile, Phe, Tyr, and Sar

fraction is the sum of $y_{5}{ }^{+2}$ and $y_{5}$ signals. In agreement with earlier results [17] the most prominent fragmentation reaction is cleavage of the second amide bond. In many cases this fragmentation mode represents $60-70 \%$ of the totals fragmentation with, in general, little dependence on the identity of Xaa and little dependence on symmetric versus asymmetric cleavage of the amide bond. The extent of cleavage of the second amide bond is slightly lower when 

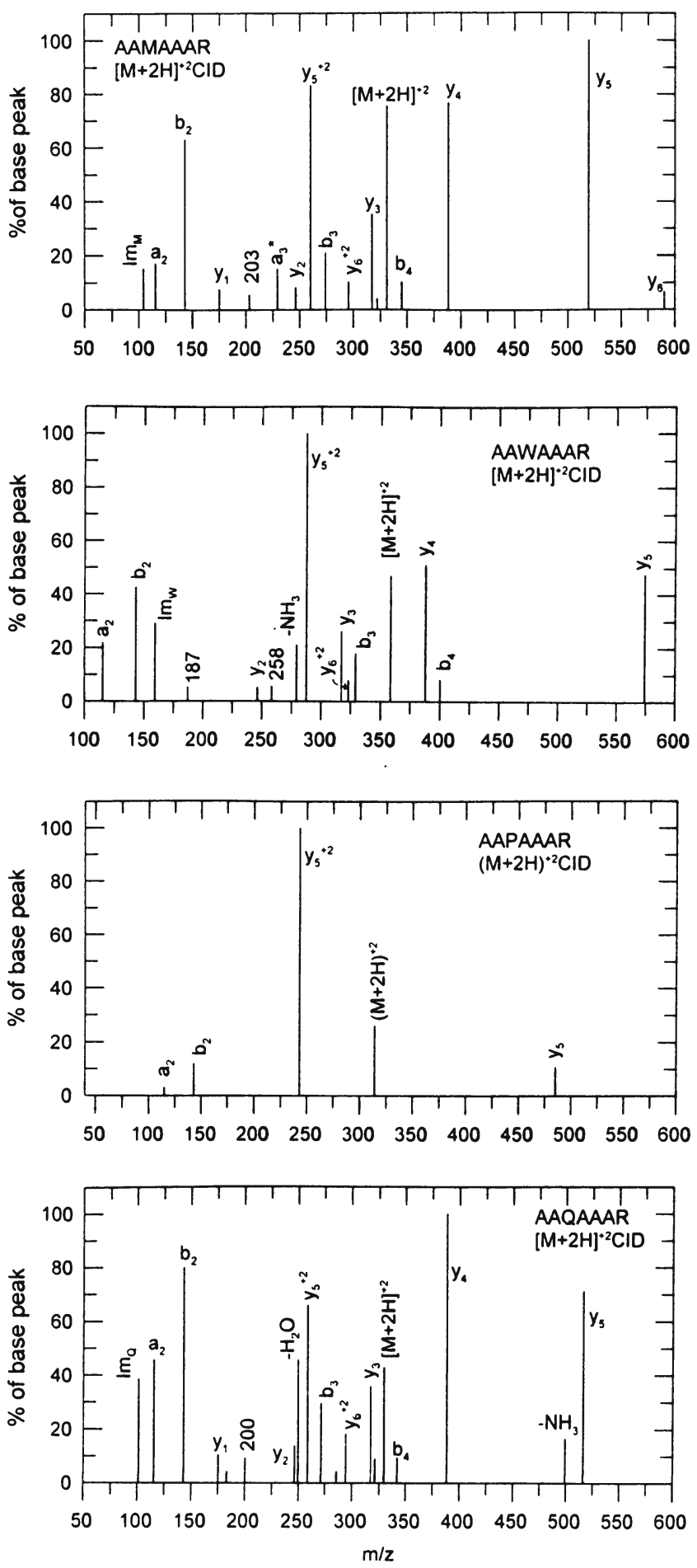

Figure 3. $[\mathrm{M}+2 \mathrm{H}]^{+2}$ product ion mass spectra when $\mathrm{Xaa}=$ Met, Trp, Pro, and Gln

Xaa is Val or Ile where cleavage of the third amide bond (Nterminal to Val or Ile ) is enhanced (Table 2), as has been noted previously $[13,15]$. The total extent of cleavage of $[\mathrm{M}+2 \mathrm{H}]^{+2}$ is considerably greater when Xaa is Ser or Thr (Table 1); this is largely due to facile loss of $\mathrm{H}_{2} \mathrm{O}$ in these cases, although for $\mathrm{Thr}$ there also is an unexpected (and unexplained) enhanced cleavage of amide bond four (Table 2).

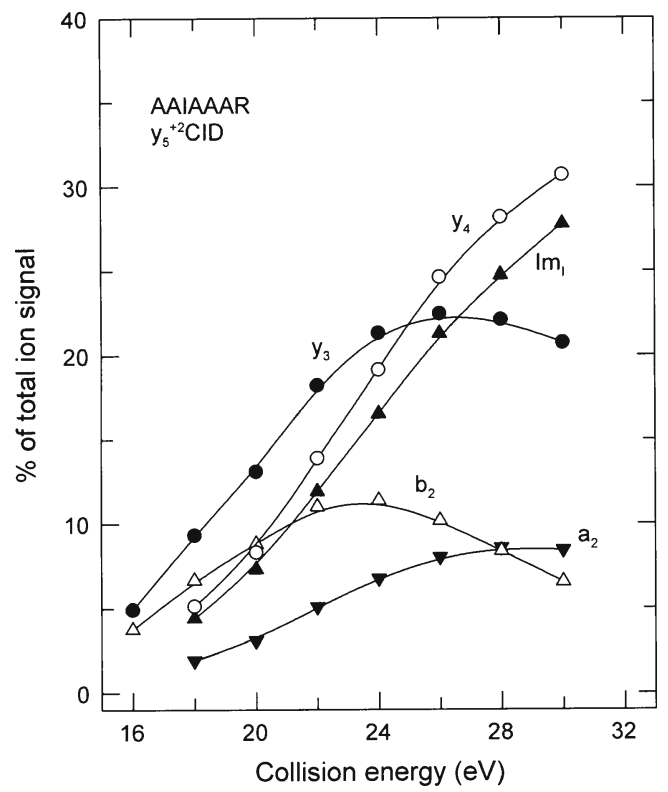

Figure 4. Breakdown graph for $y_{5}{ }^{+2}$ ion derived from AAIAAAR

Peptide $[\mathrm{M}+2 \mathrm{H}]^{+2}$ ions containing Sar or Pro also show a high total extent of fragmentation (Table 1). This is largely (Sar) or exclusively (Pro) reflected in the increased cleavage of the second amide bond (Table 2); i.e., cleavage Nterminal to the Xaa residue. Preferential cleavage N-terminal to Pro in tryptic peptides has been noted previously $[9,16]$. Vaisar and Urban [27] have reported that singly-protonated pentapeptides with Pro in the central position show enhanced cleavage N-terminal to Pro (to produce $y_{3}$ ). They also reported that replacement of Pro with Sar in these peptides also resulted in enhanced cleavage to produce $y_{3}$ although not to the extent that Pro did. These results, along with our present results for the Sar case, suggest that a significant part, but not all, of the proline effect arises from the tertiary nature of the amide nitrogen, in the present case at the second amide bond. The proline effect also is not entirely related to the high proton affinity of proline $\left(225 \mathrm{kcal} \mathrm{mol}^{-1}\right.$ [28]) since the proton affinity of sarcosine (220 kcal mol $\left.{ }^{-1}[29]\right)$ is considerably lower yet a strong tendency for $\mathrm{N}$-terminal cleavage still is observed.

Upon cleavage of the second amide bond there clearly is a competition between symmetric bond cleavage to produce the $y_{5} / b_{2}$ ion pair and asymmetric bond cleavage to produce $\mathrm{y}_{5}{ }^{+2}$ and a neutral $\mathrm{b}_{2}$ fragment. With the $\mathrm{b}_{2}$ species remaining constant in the present study one would expect that the yield of $\mathrm{y}_{5}{ }^{+2}$ should increase as the second proton affinity of singly-protonated Xaa-Ala-Ala-Ala-Arg increases. Such second proton affinities are not known; as a crude approximation, we assume they will be related to the proton affinity of $\mathrm{H}-\mathrm{Xaa}-\mathrm{OH}$. The relevant data, i.e., the ratio $\mathrm{y}_{5}{ }^{+2} / \mathrm{y}_{5}$ and $\mathrm{PA}(\mathrm{H}-\mathrm{Xaa}-\mathrm{OH})$ are assembled in Table 3; the intensity ratios are the average of the ratios obtained at low collision energies before further fragmentation is observed. Figure 5 shows an attempted linear free energy 
Table 1. $\%$ of total ionization for various ions (24 eV CE)

\begin{tabular}{lrrrcccc}
\hline Xaa & $\mathrm{y}_{5}{ }^{+2}$ & $\mathrm{y}_{5}$ & \multicolumn{1}{c}{$\mathrm{y}_{4}$} & \multicolumn{1}{c}{$\mathrm{y}_{3}$} & $\mathrm{y}_{2}$ & $\Sigma \mathrm{y}$ & {$[\mathrm{M}+2 \mathrm{H}]^{+2}$} \\
\hline Ala & 4.1 & 18.7 & 5.5 & 4.1 & & 32.4 & 33.1 \\
Ser & 3.4 & 17.2 & 2.3 & 3.1 & & 26.0 & 21.9 \\
Val & 11.6 & 12.1 & 13.2 & 4.4 & 1.0 & 42.3 & 31.1 \\
Thr & 5.6 & 8.6 & 2.8 & 14.4 & & 31.4 & 11.6 \\
Ile & 13.9 & 8.8 & 12.6 & 4.4 & & 39.7 & 34.9 \\
Phe & 13.3 & 12.2 & 6.4 & 4.1 & 1.1 & 37.1 & 33.8 \\
Tyr & 11.6 & 12.3 & 6.3 & 4.1 & 1.0 & 35.3 & 45.1 \\
Sar & 35.7 & 18.0 & 8.1 & & & 61.8 & 10.6 \\
Met & 12.8 & 13.0 & 9.3 & 4.7 & & 39.8 & 39.9 \\
Trp & 17.3 & 6.7 & 6.2 & 3.8 & & 34.0 & 48.8 \\
Pro & 65.9 & 7.1 & & & & 73.0 & 17.2 \\
Gln & 11.2 & 5.1 & 7.7 & 3.0 & & 27.0 & 56.4 \\
\hline
\end{tabular}

correlation [30] in a plot of $\ln \left(\mathrm{y}_{5}+2 / \mathrm{y}_{5}\right)$ versus PA(H-Xaa$\mathrm{OH})[28,29]$. Clearly, a satisfactory linear correlation is not observed but the trend is very clear. The lack of a good linear correlation undoubtedly is due, in part, to the poor approximation of the second proton affinities of singlyprotonated Xaa-Ala-Ala-Ala-Arg. It also is likely that structural and conformational effects play a significant role in the competition between symmetric and asymmetric amide bond cleavage. The point for Xaa $=$ Pro is higher than any of the other results. This is more evident from the ratios themselves (Table 3) which shows a $\mathrm{y}_{5}{ }^{+2} / \mathrm{y}_{5}$ ratio of 10.16 for $\mathrm{Xaa}=$ Pro while all the other peptides show ratios between 0.2 and 2.6. This result is in agreement with the more qualitative results of Aebersold and coworkers [20] who observed enhanced formation of doubly-protonated y ions formed by fragmentation N-terminal to the Pro residue in doubly- and triply-protonated tryptic peptides with fully or partially mobile protons. However, it should be noted that the N-terminal Ala-Ala provides a rather unfavorable case for observation of symmetrical amide bond cleavage because of the relatively low stability of the Ala-Ala $b_{2}$ ion. In a recent study [14], it was observed that replacement of either of the Ala residues with a Tyr residue, as in Tyr-Ala-ProAla-Ala-Ala-Arg and Ala-Tyr-Pro-Ala-Ala-Ala-Arg, resulted in a substantial increase in the extent of symmetric bond cleavage. At low collision energies the $\mathrm{y}_{5}{ }^{+2} / \mathrm{y}_{5}$ ratio was 2.66 for the first case and 2.35 for the second case, much reduced from the value of 10.16 noted above.

Table 2. Fractional cleavage of amide bonds (24 eV CE)

\begin{tabular}{lcccc}
\hline Xaa & Bond 2 & Bond 3 & Bond 4 & Bond 5 \\
\hline Ala & 0.70 & 0.17 & 0.13 & \\
Ser & 0.79 & 0.09 & 0.12 & \\
Val & 0.56 & 0.31 & 0.10 & 0.02 \\
Thr & 0.45 & 0.09 & 0.46 & \\
Ile & 0.57 & 0.32 & 0.11 & \\
Phe & 0.69 & 0.17 & 0.11 & 0.03 \\
Tyr & 0.68 & 0.18 & 0.12 & 0.02 \\
Sar & 0.87 & 0.13 & & \\
Met & 0.65 & 0.23 & 0.12 & \\
Trp & 0.71 & 0.18 & 0.11 & \\
Pro & 1.00 & & & \\
Gln & 0.60 & 0.19 & 0.11 & \\
\hline
\end{tabular}

Table 3. $\ln \left(\mathrm{y}_{5}{ }^{+2} / \mathrm{y}_{5}\right)$ as a function of $\mathrm{PA}(\mathrm{H}-\mathrm{Xaa}-\mathrm{OH})$

\begin{tabular}{lccc}
\hline Xaa & $\mathrm{y}_{5}{ }^{+2} / \mathrm{y}_{5}$ & $\ln \left(\mathrm{y}_{5}{ }^{+2} / \mathrm{y}_{5}\right)$ & $\mathrm{PA}(\mathrm{H}-\mathrm{Xaa}-\mathrm{OH})^{\mathrm{a}}$ \\
\hline Ala & 0.21 & -1.56 & 215.5 \\
& 0.19 & -1.66 & 218.1 \\
Val & 0.97 & -0.030 & 218.5 \\
Thr & 0.61 & -0.49 & 219.4 \\
Ile & 1.27 & 0.24 & 219.5 \\
Phe & 1.08 & 0.077 & 220.7 \\
Tyr & 0.93 & -0.073 & 221.5 \\
Sar & 2.47 & 0.90 & $220.0^{\mathrm{b}}$ \\
Met & 1.06 & 0.058 & 223.8 \\
Trp & 2.55 & 0.94 & 224.7 \\
Pro & 10.16 & 2.32 & 225.1 \\
Gln & 2.41 & 0.88 & 232.2 \\
\hline
\end{tabular}

${ }^{\mathrm{a}} \mathrm{PAs}$ (in $\mathrm{kcal} \mathrm{mol}^{-1}$ ) from reference [28] unless otherwise noted.

${ }^{\mathrm{b}}$ From reference [29].

\section{Conclusions}

The present study of doubly-protonated Ala-Ala-Xaa-AlaAla-Ala-Arg peptides provides further examples of preferential cleavage at the second amide bond upon collisional activation of tryptic-type peptides [17]. With a few notable exceptions, the results show that this preference is independent of the identity of Xaa and, largely, depend on whether the bond cleavage occurs symmetrically to produce a $\mathrm{y}_{5} / \mathrm{b}_{2}$ ion pair or whether it occurs asymmetrically to produce $\mathrm{a}_{5}{ }^{+2}$ ion and a neutral $\mathrm{b}$ species. The original study [17] considered only symmetric charge separation reactions.

A notable exception to the general behavior occurs when $\mathrm{Xaa}=$ Pro and, to a lesser extent, when Xaa $=$ Sar. For Xaa = Pro, only cleavage of the second amide bond is observed while for Xaa = Sar, cleavage of the second amide bond is considerably enhanced compared with other residues. The similarity of the fragmentation modes for the peptides containing Pro and Sar suggests that, in part, the proline effect arises from the tertiary nature of the amide nitrogen of the amide bond being cleaved. In cleavage of the second amide bond, there is competition between asymmetric bond cleavage to produce $\mathrm{y}_{5}^{+2}$ and a neutral $\mathrm{b}_{2}$ species and symmetric bond cleavage to produce the $\mathrm{y}_{5} / \mathrm{b}_{2}$ ion pair. The extent of asymmetric bond cleavage increases as the second

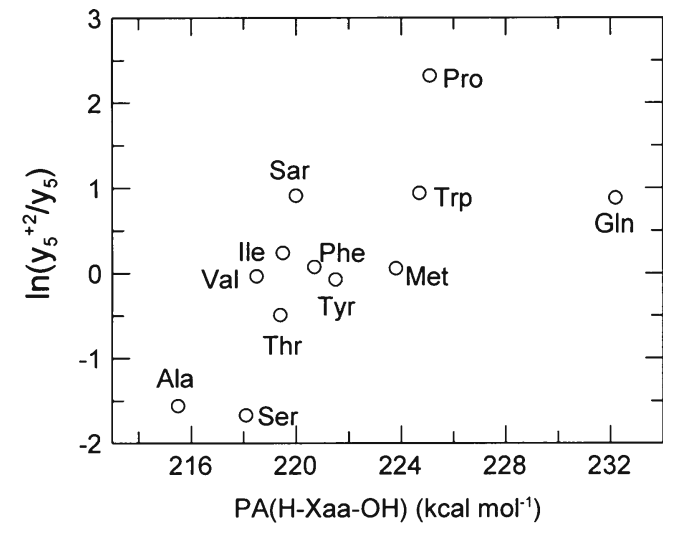

Figure 5. A plot of $\ln \left(\mathrm{y}_{5}+2 / \mathrm{y}_{5}\right)$ as a function of $\mathrm{PA}(\mathrm{H}-\mathrm{Xaa}-\mathrm{OH})$ 
proton affinity of singly-protonated Xaa-Ala-Ala-Ala-Arg increases. However, this second proton affinity is not adequately represented by the proton affinity of H-Xaa$\mathrm{OH}$. Again the Pro residue shows a unique behavior in giving a much higher $\mathrm{y}_{5}{ }^{+2} / \mathrm{y}_{5}$ ratio than any of the other residues

\section{Acknowledgement}

The author gratefully acknowledges the continued financial support of the Natural Sciences and Engineering Research Council (Canada).

\section{References}

1. Larsen, M.R., Roepstorff, P.: Mass spectrometric identification of proteins and characterization of their post-translational modifications in proteome analysis. Fresenius J. Anal. Chem. 366, 677-690 (2000)

2. Aebersold, R., Goodlett, D.R.: Mass spectrometry in proteomics. Chem. Rev. 101, 269-295 (2001)

3. Medzihradszky, K.F.: Peptide sequence analysis. Meth. Enzymol. 402, 209-244 (2005)

4. Wysocki, V.H., Tsaprailis, G., Smith, L.L., Breci, L.A.: Mobile and localized protons. A framework for understanding peptide dissociation. J. Mass Spectrom. 35, 1399-1406 (2000)

5. Paizs, B., Suhai, S.: Fragmentation pathways of protonated peptides. Mass Spectrom. Rev. 24, 508-548 (2005)

6. Harrison, A.G.: To $b$ or not to $b$ : the ongoing saga of peptide $b$ ions. Mass Spectrom. Rev. 28, 640-654 (2009)

7. Vékey, K., Candido, M., Traldi, P.: Use of charge separation reactions for sequencing peptides. Rapid Commun. Mass Spectrom. 4, 74-76 (1990)

8. Tang, X.-J., Boyd, R.K.: An investigation of fragmentation of doubly protonated tryptic peptides. Rapid Commun. Mass Spectrom. 6, 651657 (1992)

9. Loo, J.A., Edmonds, C.G., Smith, R.D.: Tandem mass spectrometry of very large molecules. 2. dissociation of multiply charged prolinecontaining proteins from electrospray ionization. Anal. Chem. 65, 425438 (1993)

10. Tang, X.-J., Thibault, P., Boyd, R.K.: Fragmentation reactions of multiply-protonated peptides and implications for sequencing by tandem mass spectrometry with low-energy collision-induced dissociation. Anal. Chem. 65, 2824-2834 (1993)

11. Harrison, A.G.: Charge separation reactions of doubly-protonated peptides: effect of peptide chain length. J. Am. Soc. Mass Spectrom. 20, 1890-1895 (2009)

12. Knapp-Mohammedy, M., Young, A.B., Paizs, B., Harrison, A.G.: Fragmentation of doubly-protonated Pro-His-Xaa tripeptides: formation of $b_{2}{ }^{+2}$ Ions. J. Am. Soc. Mass Spectrom. 20, 2135-2143 (2009)
13. Goduku, B., Neta, P., Simón-Manso, Y., Stein, S.E.: Effect of Nterminal glutamic acid and glutamine on fragmentation of peptide ions. J. Am. Soc. Mass Spectrom. 21, 1169-1176 (2010)

14. Harrison, A.G.: Effect of proline position on symmetric versus asymmetric fragmentation of doubly-protonated tryptic-type peptides. Int. J. Mass Spectrom, 2011.

15. Tabb, D.L., Smith, L.L., Breci, L.A., Wysocki, V.H., Lin, D., Yates, J. R.: III. Statistical characterization of ion trap tandem mass spectra from doubly charged tryptic peptides. Anal. Chem. 75, 1155-1163 (2003)

16. Breci, L.A., Tabb, D.L., Yates, J.R.I.I.I., Wysocki, V.H.: Cleavage Nterminal to proline: analysis of a database of peptide tandem mass spectra. Anal. Chem. 75, 1963-1971 (2003)

17. Savitski, M.M., Fälth, M., Fung, Y.M.E., Adams, C.E., Zubarev, R.A.: Bifurcating fragmentation behavior of gas-phase tryptic peptide dications on collisional activation. J. Am. Soc. Mass Spectrom. 19, 17551763 (2008)

18. Bythell, B.J., Somogyi, Á., Paizs, B.: What is the structure of $b_{2}$ ions generated from doubly-protonated tryptic peptides. J. Am. Soc. Mass Spectrom. 20, 628-624 (2009)

19. Bythell, B.J., Erlekam, U., Paizs, B., Maître, P.: Infrared spectroscopy of fragments from doubly-protonated tryptic peptides. Chem. Phys. Chem. 10, 883-885 (2009)

20. Martin, D.B., Eng, J.K., Nesvizhskii, A.I., Gemmill, A., Aebersold, R.: Investigation of neutral loss during collision-induced dissociation of peptide ions. Anal. Chem. 77, 4870-4882 (2005)

21. Ballard, K.D., Gaskell, S.J.: Dehydration of peptide $[\mathrm{M}+\mathrm{H}]^{+}$ions in the gas phase. J. Am. Soc. Mass Spectrom. 4, 477-481 (1993)

22. van Dongen, W.D., de Koster, C.G., Heerma, W., Haverkamp, J.: The diagnostic value of the $m / z 102$ peak in the positive ion fast-atom bombardment mass spectra of peptides. Rapid Commun. Mass Spectrom. 9, 845-850 (1995)

23. Dookeran, N.N., Yalcin, T., Harrison, A.G.: Fragmentation reactions of protonated $\alpha$-amino acids. J. Mass Spectrom. 31, 500-508 (1996)

24. O'Hair, R.A.J., Reid, G.E.: Does side chain water loss from protonated threonine yield N-protonated dehydroamino-2-butryic Acid? Rapid Commun. Mass Spectrom. 12, 999-1002 (1998)

25. Reid, G.E., Simpson, R.J., O’Hair, R.A.J.: Leaving group and gas phase neighboring group effects in side chain losses from protonated serine and its derivatives. J. Am. Soc. Mass Spectrom. 11, 104-1060 (2000)

26. Nata, P., Pu, Q.-L., Yang, K., Stein, S.E.: Consecutive losses of $\mathrm{H}_{2} \mathrm{O}$ and $\mathrm{C}_{2} \mathrm{H}_{4} \mathrm{O}$ from $\mathrm{N}$-terminal Thr-Thr and Thr-Ser in collision-induced dissociation of protonated peptides. Position dependent water loss from single Thr or Ser. Int. J. Mass Spectrom. 267, 295-301 (2007)

27. Vaisar, T., Urban, J.: Probing the proline effect in CID of protonated peptides. J. Mass Spectrom. 31, 1185-1187 (1996)

28. Gronert, S., Simpson, D.C., Conner, K.M.: A Re-evaluation of computed proton affinities for the common $\alpha$-amino acids. J. Am. Soc. Mass Spectrom. 20, 2116-2123 (2009)

29. Hunter, E.P.L., Lias, S.G.: Evaluated gas phase basicities and proton affinities of molecules: an update. J. Phys. Chem. Ref. Data 27, 413656 (1998)

30. Harrison, A.G.: Linear free energy correlations in mass spectrometry. J. Mass Spectrom. 34, 577-589 (1999) 